\title{
Birds That Vanish While We Turn Our Backs
}

\author{
Simon N. Stuart
}

Thirteen forest bird species are seriously threatened in East Africa - one, a bush shrike, may already be extinct. But the very small surviving area of forest is being rapidly destroyed, and soil eroded. If the tree-felling can be stopped it could both save the rare birds and stop the erosion. The author's study of these forest birds was aided by the FPS Oryx 100\% Fund.

Most of the very rare East African birds are forest species, and today forest covers only three per cent of the land surface in this region. Even this is rapidly declining. By far the most crucial areas for rare bird species are the Arabuko-Sokoke Forest in coastal Kenya, the East and West Usambara Mountains in north-eastern Tanzania, and the Uluguru Mountains, $150 \mathrm{~km}$ west of Dar es Salaam; the avifauna of these areas is unique. ${ }^{8}$ Next in importance are the forests of the Tana River and Shimba Hills in coastal Kenya, the Taita Hills near Tsavo National Park, the Nguru and Ukaguru Mountains in eastern Tanzania, and the Pugu Hills near Dar es Salaam. Thirteen bird species are threatened in these areas due to their very small ranges - see the table.

The tiny Sokoke scops owl Otus ireneae was only discovered in $1965,{ }^{6}$ and is still only known from the Sokoke Forest. Here it is restricted to the Cynometra-Manilkara forest, where it occurs at a density of 7 to 8 pairs per sq $\mathrm{km}$, giving a total population for the forest reserve of $1300-1500$ pairs. $^{3}$ This is higher than was once thought, but the future of this forest is still uncertain, and the species must be regarded as seriously threatened.

The Sokoke pipit Anthus sokokensis is remarkable in that it inhabits coastal forest and forest edge, and not the open grassy areas that are the characteristic habitat of the genus. Numbers in the Sokoke Forest are estimated at 3000-5000

Occurrence of rare endemic species

Sokoke scops owl

Sokoke pipit

Uluguru bush-shrike

Dappled mountain spot-throat

Usambara alethe

Long-billed apalis

Mrs Moreau's warbler

Banded green sunbird

Amani sunbird

Moreau's sunbird

Loveridge's sunbird

Clarke's weaver

Usambara weaver

Number of species

$$
\begin{aligned}
& \text { EU }=\text { East Usambara } \\
& \mathbf{W U}=\text { West Usambara } \\
& \mathbf{U k}=\text { Ukaguru } \\
& \mathbf{N g}=\text { Nguru }
\end{aligned}
$$

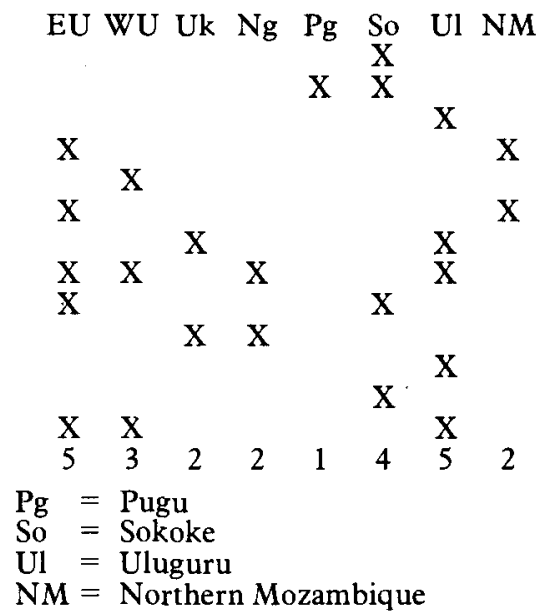




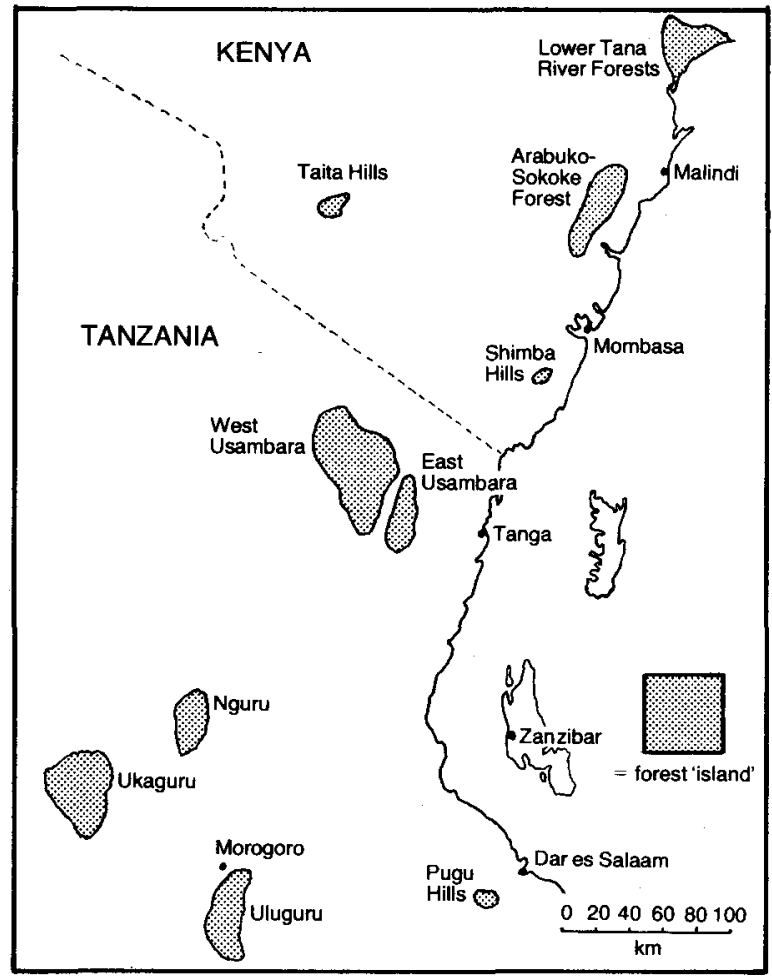

pairs. ${ }^{3}$ Elsewhere it has been recorded from a small patch of forest at Moa, near Tanga, ${ }^{7}$ which may no longer exist, and from the Pugu Hills where it has not been recorded since $1938,{ }^{5}$ and a recent search proved fruitless. The bulk of its population must now be restricted to the Sokoke Forest.

Also restricted to the Sokoke Forest is Clarke's weaver Ploceus golandi, about which very little is known, since it is only present in Sokoke at certain times of year, principally from August to October. ${ }^{3}$ Where it goes for the remainder of the year is quite unknown. Occasionally it is seen in flocks, but numbers are probably not high, and its future must depend on the conservation of the Sokoke Forest.

The Usambara Mountains are a major centre for three bird species which may have world populations of under 1000 . The dappled mountain spot-throat Modulatrix orostruthus is known from only 19 individuals. The first was collected from Namuli Mountain in northern Mozambique, ${ }^{10}$ where a small population might still survive; the other 18 are all from Amani in the East Usambaras, from the ground stratum of forest at $900 \mathrm{~m}$, where it occurs at a very low density, its population being tentatively estimated at 200 . Its future depends on controlling the forest clearance, which is proceeding rapidly.

The long-billed apalis Apalis moreaui, a strange warbler with a disproportionately long bill and a distinctive song that makes it difficult to overlook, has a distribution reminiscent of the dappled mountain spot-throat. It has only been recorded from the East Usambaras, where it is very uncommon, occurring mainly in dense viny habitats around the forest edge, and on the Njesi Plateau in northern Mozambique, where any population must be very small ${ }^{4}$; there have been no records from Niesi Plateau since 1946. The third rarity is the Usambara weaver Ploceus nicolli. The bulk of its population is in the West Usambaras (although it has been recorded in the East) and even there 
it is only seen occasionally in the forest canopy and edge. The population here may not exceed a few hundred, and there is evidence of a decline, even in areas that have not been deforested. In the East Usambaras, and the Ulugurus where it has been collected twice, the very small populations may now be extinct.

The Usambara alethe Dryocichloides montanus is confined to the West Usambara Mountains. Its world population is much higher than originally thought, perhaps as many as 30,000 individuals. However these are almost entirely restricted to two small areas (the Shume-Magamba and Shagayu Forest Reserves) which are one of the major centres for logging. The bird's future is far from secure.

The banded green sunbird Anthreptes rubritorques is common in the forest canopy in the East Usambaras; even in the West Usambaras and the Ngurus, where it is rarer, it is unlikely to be immediately endangered unless forest destruction gets completely out of control. Recently a few records have come to light of this species in the Uluguru Mountains. ${ }^{1}$ The Amani sunbird Anthreptes pallidigaster occurs in the East Usambaras where it is uncommon, though sizeable flocks have occasionally been recorded, and in the Sokoke, where its population is estimated at approximately $2900-4700$ pairs and so probably not in any immediate danger. ${ }^{2}$ But the ranges of these two sunbirds are so small that their status needs to be watched.

The Uluguru Mountains are the only home of what could well be the rarest bird in Africa, the Uluguru bush-shrike Malaconotus alius, known only from the Bagilo area. There have been no records since $1961,{ }^{1}$ and a recent report suggests that little forest now remains in the Bagilo area. The bird may already be extinct.

Mrs Moreau's warbler Bathmocercus winifredae, still quite common in the Uluguru and Ukaguru Mountains but occurring nowhere else, is likely to survive as long as areas of forest with dense undergrowth remain. Loveridge's sunbird Nectarinia loveridgei is still common in the Ulugurus, to which it is completely restricted, but again close observation is essential, simply because of its small range; the same applies to the closely related Moreau's sunbird Nectarinia moreaui which is common in the Nguru, Ukaguru and Uvidunda Mountains to the west of the Ulugurus.

In addition to these thirteen threatened species there are a further 21 species with restricted distributions in these forests. None is yet endangered, but their existence is another argument in favour of conserving the forests. They include the spotted ground-thrush Turdus fischeri, the spot-throat Modulatrix stictigula, the East Coast akalat Sheppardia gunningi, Sharpe's akalat $S$. sharpei, the white-winged apalis Apalis chariessa, and the green-headed oriole Oriolus chlorocephalus. In addition a distinctive subspecies of the olive thrush, Turdus olivaceus helleri, occurs in the Taita Hills, and there are several isolated subspecies of West African forest birds in this part of East Africa. Some of these are very rare, perhaps the most endangered being the nduk eagle owl Bubo poensis vosseleri. ${ }^{11}$

Another reason for a tightened conservation policy for all these forests is their extraordinarily high species diversity, in addition to their many rare animals and plants, especially in the Usambaras and Ulugurus. All too often the result of forest clearance is severe soil erosion and lowering of the water table, with very little agricultural benefit.

Except in the Nguru and Ukaguru Mountains, forest destruction is 
proceeding rapidly; in parts of the Usambaras the situation is becoming quite desperate. But it does now seem more likely that the Tanzanian Government will act to stop the destruction although lack of funds and man power will create problems in enforcement. Many scientists regard these localities as the areas most in need of further protection in East Africa, and conservation organisations need to help.

\section{References}

1. BRITTON, P.L. 1978. The Andersen collection from Tanzania. Scopus 2: 77-85.

2. BRITTON, P.L., and H.A. BRITTON 1978. Notes on the Amani sunbird Anthreptes pallidigaster, including a description of the nest and eggs. Scopus 2: 102-3.

3. BRITTON, P.L., and D.A. ZIMMERMANN 1979. The avifauna of Sokoke Forest, Kenya. F. of the East African Nat. Hist. Soc, and National Mus. 169: 1-15.

4. HALL, B.P., and R.E. MOREAU 1962. A study of the rare birds of Africa. Bull. of the Brit. Mus. (Nat. Hist.). Zoology 8: 313-78.

5. MOREAU, R.E. 1940. Distributional notes on East African birds. Ibis 14th series 4: 454-63.

6. RIPLEY, S.D. 1966. A notable owlet from Kenya. Ibis 108: 136-7.

7. SCLATER, W.L., and R.E. MOREAU 1932. Taxonomic and field notes on some birds of north-eastern Tanganyika Territory, Part II. Ibis 13th series 2: 656-83.

8. STUART, S.N. (in press). A comparison of the avifaunas of seven East African forest 'islands'. A frican fournal of Ecology.

9. VAN DER WILLIGEN, T.A. (ed.) 1980. Report of the Oxford Expedition to Tanzania 1979. Cyclostyled, Oxford.

10. VINCENT, J. 1933. Phyllastrephus orostruthus sp. nov. Bulletin of the British Ornithologists' Club 53: 133.

11. WHITE, G.B. 1974. Rarest Eagle Owl in Trouble. Oryx 12: 484-6.

Simon N. Stuart, Mazumbai Estate, Box 44, Soni, Tanzania, and Department of Applied Biology, Pembroke Street, Cambridge CB2 3DX, U.K.

\section{New Mangabey in Tanzania}

\section{K.A. Homewood and W.A. Rodgers write:}

In November 1979 we recorded a new mangabey monkey, allied to Cercocebus galeritus, from a mountain range in southern Tanzania. To date the species is known from the Congo forest block (Gabon, Zaire) and from north Kenya, so this new record has important taxonomic and biogeographic considerations. The new form must await formal classification, as the size of the population precludes collecting a type specimen, but a captive juvenile is kept at the $\mathrm{Mt}$ Meru Game Sanctuary in Arusha.

From our brief field observations and questioning of local villagers, who know the monkey well and were surprised at our ignorance of its existence, the race appears to be confined to two small forest areas totalling less than $200 \mathrm{sq}$ $\mathrm{km}$, so numbers must be dangerously low. Their habitat is within gazetted forest reserves, but increasing land and timber demands create concern for their long-term conservation. The Tanzania National Scientific Research Council is providing funds towards a preliminary field survey to determine distribution patterns, but much more study will be required before effective conservation measures can be implemented. 